\title{
Chemicals Reactions, Making Process and Behaviour of Dry Cement
}

\author{
Vivek Sharma \\ Ph.D. Scholar, Manipal University Jaipur, Jaipur \\ E-mail: mailtovivek3@gmail.com
}

\section{Abstract}

In this research a number of techniques are studied. The OPC is silicate concrete typically used for solid brick work units and for all uses where the solid isn't needy upon remarkable sulfate risk or where the warmth delivered by the hydration of concrete isn't frightful. It has unfathomable opposition from breaking however has a littler measure of obstruction from substance assaults. Watchwords: OPC, Limestone, clinker and so on.

Keywords: Dry Cement, limestone, Portland cement etc.

\section{INTRODUCTION}

It is characterized as the bonding material taking consistent and cement assets which makes it able to join the diverse development materials. OPC is accepted to be future item considering of it as different applications in the development business. They are appropriate to use in hostile environmental conditions. They can be dependably used in the development of marine structures, masonry mortars and plastering, hydraulic structures. Also, they are prevalently utilized in mass concreting works, for example, dykes, sewage pipes, dams, and so on.

\section{MANUFACTURE OF OPC CEMENT}

Cement is a hydraulic binder and is defined as a finely ground inorganic material which, when mixed with water, forms a paste which sets and hardens by means of hydration reactions and processes which, after hardening retains it's strength and stability even under water. OPC is one of a few kind of cement being produced all through the world. Magnesium $(\mathrm{MgO})$ is available in little amounts as a polluting influence related with limestone. SO3 is added at the grinding stage to impede the setting time of the completed cement. At the point when cement raw materials containing the best possible extents of the basic oxides are ground to an appropriate fineness and afterward consumed to nascent combination in an oven, chemical mix happens, to a great extent 
in the strong state bringing about an item suitably named clinker. Significantly there are 4 stages associated with the OPC cement,

\section{Crushing and grinding of raw material}

Firstly, Soft raw materials are squashed into reasonable size. It is completed for the most part in cylindrical ball holding the charge of steel balls.

\section{Mixing or Blending}

Now the crushed limestone is blended in with the clay paste in legitimate extent ( $75 \%=$ lime stone; clay $=25 \%$ ). In the dry process these mixes are stored in silos; slurry tanks are used in the wet process. Silos and slurry tanks can be used to put away these mix in dry and wet process respectively

\section{Heating}

The rotational kiln comprises of big cylinders 8 to 15 feet in diameter \& height of 300-500 feet. Firstly the mix is preheated to $550 \mathrm{C}$, where all the dampness content is evaporated and clay is broken into silica, aluminum oxide, iron oxide.

In the following zone the temperature is raised to 1500 degree Celsius where the oxides structure separate silicate, aluminates and ferrite. In the last step the item is chilled off to 200C. Kiln rotates at the rate of 1-2 revolution per minute. In rotary kiln, slurry is passed through different zones of temperature. This whole process in kiln usually covers 2 to 3 hours.

\section{Grinding}

The Cement Clinker is then air cooled. the cement clinkers and gypsum grinded into fine powders which are put away in the storehouses. At long last cement is filled in bags and afterward moved to the necessary site. 


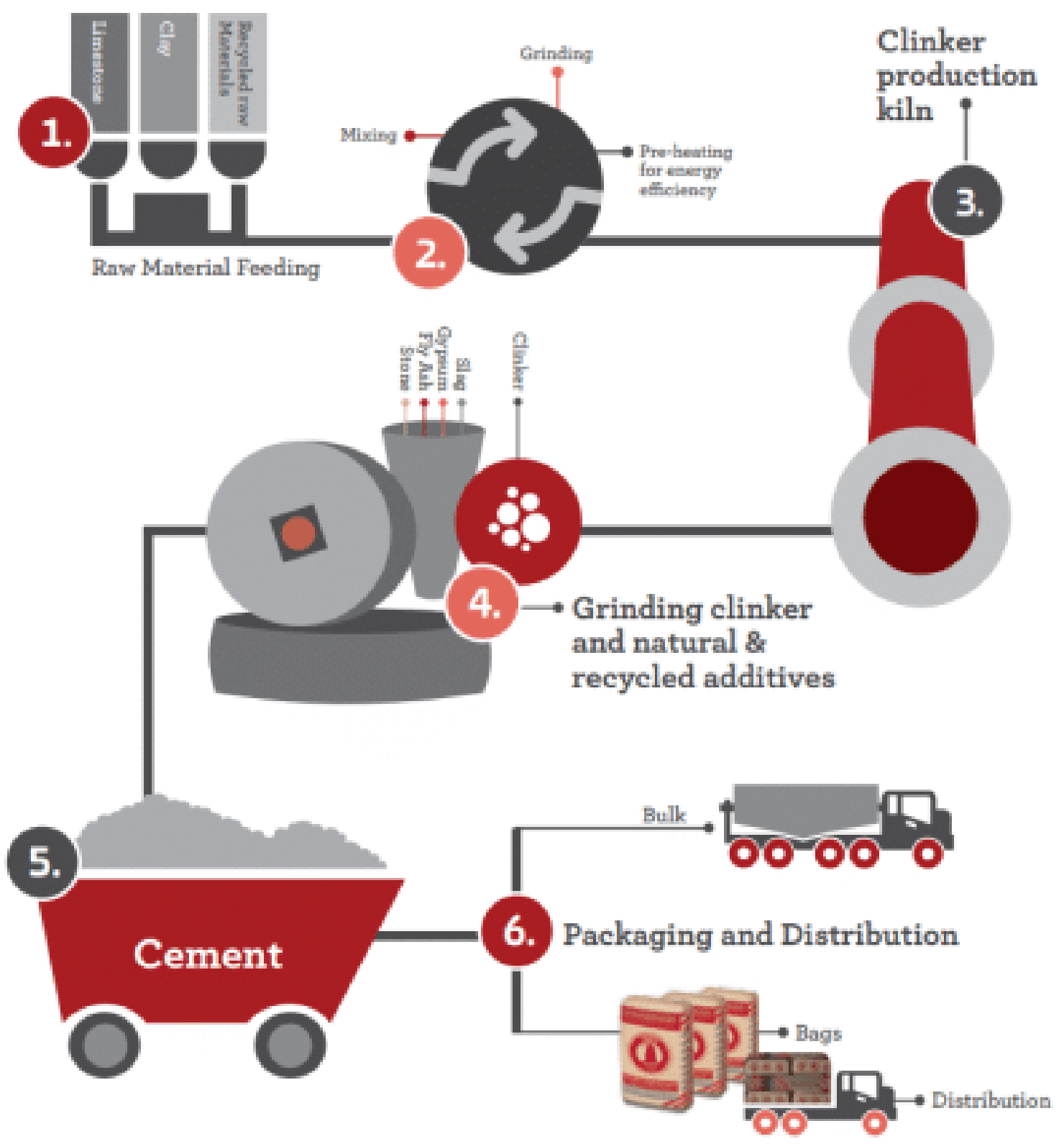

Fig 1: Manufacturing process of ordinary Portland cement 
TABLE 1

VARIOUS DETERMINANTS IN OPC

\begin{tabular}{|l|l|}
\hline Constituent & OPC(\% by weight) \\
\hline Lime & 65.64 \\
\hline Silica & 22.20 \\
\hline Alumina & 5.53 \\
\hline Iron oxide & 3.36 \\
\hline Magnesia & 2.08 \\
\hline Sulphu Trioxide & 2.23 \\
\hline $\mathrm{N}_{2} \mathrm{O}$ & 0.06 \\
\hline Loss of Ignition & 0.62 \\
\hline Lime saturation factor & 0.95 \\
\hline
\end{tabular}

TABLE 2

PROPERTIES OF OPC CEMENT

\begin{tabular}{|l|l|}
\hline Properties & Values \\
\hline Specific Gravity & 3.12 \\
\hline Normal Consistency & $29 \%$ \\
\hline Initial Setting time & $65 \mathrm{~min}$ \\
\hline Final Setting time & $275 \mathrm{~min}$ \\
\hline Fineness & $330 \mathrm{~kg} / \mathrm{m}^{2}$ \\
\hline Soundness & $2.5 \mathrm{~mm}$ \\
\hline Bulk Density & $830-1650 \mathrm{~kg} / \mathrm{m}^{3}$ \\
\hline
\end{tabular}

\section{CONCLUSION}

The crude materials for Portland concrete are essentially made out of three sections: calcium oxide, silicon dioxide and alumina, which represent $60 \%, 20 \%$ and $10 \%$ of the absolute segment independently. The calcium oxide begins from limestone, while silica and alumina start from 
shale, soil and bauxite. What's more, most of the crude materials contain iron oxide, magnesia, calcium sulfate, etc.

\section{REFERENCES}

[1] C. M. Hanson, "Concrete: the advanced industrial material of the 21 st century," Metallurgical \& Materials Transactions A, vol. 26, pp. 1321-1341, 1995.

[2] M. Bediako, S. K. Y. Gawu, and A. A. Adjaottor, "Suitability of some Ghanaian mineral admixtures for masonry mortar formulation," Construction and Building Materials, vol. 29, pp. 667-671, 2012.

[3] S. H. Kosmatka, B. Kerkhoff, and W. C. Panarese, Design and Control of Concrete Mixtures, Portland Cement Association,Skokie, Ill, USA, 14th edition, 2002.

[4] M. S. Mamlouk and J. P. Zaniewski, Materials for Civil andConstruction Engineers, Prentice Hall, Upper Saddle River, NJ,USA, 2006.

[5] T. Punmatharith, M. Rachakornkij, A. Imyim, and M.Wecharatana, "Co-processing of grinding sludge as alternative raw material in portland cement clinker production," Journal of Applied Sciences, vol. 10, no. 15, pp. 1525-1535, 2010.

[6] D. N. Huntzinger and T. D. Eatmon, "A life-cycle assessment of Portland cement manufacturing: comparing the traditional process with alternative technologies," Journal of Cleaner Production, vol. 17, no. 7, pp. 668-675, 2009.

[7] F. M. Lea, The Chemistry of Cement and Concrete, Arnold Publishers, London, UK, 3rd edition, 1970.

[8] J. F. Young, S.Mindess, R. J. Gray, andA. Bentur,TheScience andTechnology of Civil Engineering Materials, Prentice-Hall, Upper Saddle River, NJ, USA, 1998.

[9] H. F. W. Taylor, Cement Chemistry, Thomas Telford, London,UK, 2nd edition, 1997.

[10] S. H. Kosmatka and M. L. Wilson, Design and Control of Concrete Mixtures, Portland Cement Association, Stokie, Ill, USA, 2011.

[11] V. Sata, C. Jaturapitakkul, and K. Kiattikomol, "Influence of pozzolan from various by-product materials on mechanical properties of high-strength concrete," Construction and BuildingMaterials, vol. 21, no. 7, pp. 1589-1598, 2007.

[12] A. Neville, Neville on Concrete, ACI, Farmington Hills, Mich, USA, 2003.

[13] R. Fernandez, F. Martirena, and K. L. Scrivener, "The origin of the pozzolanic activity of calcined clay minerals: a comparison between kaolinite, illite and montmorillonite," Cement and Concrete Research, vol. 41, no. 1, pp. 113-122, 2011.

[14] K. Ganesan, K. Rajagopal, and K. Thangavel, "Evaluation of bagasse ash as supplementary cementitious material," Cement and Concrete Composites, vol. 29, no. 6, pp. 515-524, 2007.

[15] S. Sinthaworn and P. Nimityongskul, "Quick monitoring of pozzolanic reactivity of waste ashes," Waste Management, vol.29, no. 5, pp. 1526-1531, 2009.

[16] J. J. Brooks,M. A.M. Johari, andM.Mazloom, "Effect of admixtures on the setting times of highstrength concrete," Cement and Concrete Composites, vol. 22, no. 4, pp. 293-301, 2000.

[17] X. Fu, Z.Wang,W. Tao et al., "Studies on blended cement with a large amount of fly ash," Cement and Concrete Research, vol. 32,no. 7, pp. 1153-1159, 2002. 
[18] E.-H. Kadri, S. Kenai, K. Ezziane, R. Siddique, and G. De Schutter, "Influence of metakaolin and silica fume on the heat of hydration and compressive strength development of mortar," Applied Clay Science, vol. 53, no. 4, pp. 704-708, 2011.

[19] V. Indrawati and A. Manaf, "Mechanical strength of trass as supplementary cementing material," Journal of Physical Science, vol. 92, no. 2, pp. 51-59, 2008. 